\title{
Quantification of Xylella fastidiosa from Citrus Trees by Real-Time Polymerase Chain Reaction Assay
}

\author{
Antonio C. Oliveira, Marcelo A. Vallim, \\ Camile P. Semighini, Welington L. Araújo, Gustavo H. Goldman, and Marcos A. Machado
}

First author: Depto de Genética e Evolução, UNICAMP, C.P. 6109 C.E.P. 13081-970 Campinas, Brazil; second, third, and fifth authors: Faculdade de Ciências Farmacêuticas de Ribeirão Preto, Universidade de São Paulo, C.E.P. 14040-903 Ribeirão Preto, Brazil; fourth author: Depto de Genética, ESALQ-USP, C.P. 83 C.E.P. 13400-970 Piracicaba, Brazil; and sixth author: Centro de Citricultura Sylvio Moreira/IAC, C.P. 04 C.E.P. 13490-000 Cordeirópolis, Brazil. Accepted for publication 12 April 2002.

\section{ABSTRACT}

Oliveira, A. C., Vallim, M. A., Semighini, C. P., Araújo, W. L., Goldman, G. H., and Machado, M. A. 2002. Quantification of Xylella fastidiosa from citrus trees by real-time polymerase chain reaction assay. Phytopathology 92:1048-1054.

Xylella fastidiosa is the causal agent of citrus variegated chlorosis (CVC), a destructive disease of sweet orange cultivars in Brazil. Polymerase chain reaction (PCR)-based assays constitute the principal diagnostic method for detection of these bacteria. In this work, we established a real-time quantitative PCR (QPCR) assay to quantify X. fastidiosa in naturally and artificially infected citrus. The X. fastidiosa cell number detected in the leaves increased according to the age of the leaf, and bacteria were not detected in the upper midrib section in young leaves, indicating temporal and spatial distribution patterns of bacteria, respectively. In addition, the $X$. fastidiosa cell number quantified in leaves of 'Pera' orange and 'Murcott' tangor reflected the susceptible and resistant status of these citrus cultivars. None of the 12 endophytic citrus bacteria or the four strains of $X$. fastidiosa nonpathogenic to citrus that were tested showed an increase in the fluorescence signal during QPCR. In contrast, all $10 \mathrm{CVC}$-causing strains exhibited an increase in fluorescence signal, thus indicating the specificity of this QPCR assay. Our QPCR provides a powerful tool for studies of different aspects of the Xylellacitrus interactions, and can be incorporated into breeding programs in order to select CVC-resistant plants more quickly.
Xylella fastidiosa is a gram-negative, nonflagellate, xylemlimited bacterial pathogen, measuring 0.1 to $0.3 \times 1.5 \mu \mathrm{m}(52)$. This bacterium belongs to the family Lysobacteriaceae, and it was the first plant pathogen to have its genome completely sequenced (48). Pathotypes of $X$. fastidiosa cause a wide range of diseases in many agriculturally important plants, including alfalfa, almond, grapevine, lucerne, peach, and plum, and in several noneconomically important plants $(21,52)$. Chang et al. (7) definitively associated a strain of $X$. fastidiosa with citrus variegated chlorosis (CVC), a destructive disease of all commercial sweet orange cultivars (Citrus sinensis (L.) Osbeck). CVC is considered the main problem faced by Brazilian citriculture and most sweet orange cultivars are susceptible to it (27). CVC's symptoms include mottled variegations on older leaves, with chlorotic areas on the upper side and corresponding light-brown lesions on the lower side. The fruits from the affected trees are small, exhibiting early ripening, and, therefore, having no commercial value (10). In Brazil, $34 \%$ of the citrus trees are affected by CVC, indicating the alarming spread of the disease in the field (14). X. fastidiosa is vectored by at least 11 sucking insects that feed on xylem-sap, such as sharpshooter leafhoppers (Homoptera, Cicadellidae) (14). Transmission also can occur through grafting in commercial nurseries (10).

The symptoms of plant bacterial diseases are not always reliable for diagnosis because they can vary according to environmental conditions (43). Limiting an outbreak of CVC requires a sensitive diagnostic procedure to prevent the spreading of $X$.

Corresponding author: M. A. Machado

E-mail address: marcos@ centrodecitricultura.br

Publication no. P-2002-0816-02R

(C) 2002 The American Phytopathological Society fastidiosa into mother plants and budwoods. Thus, diagnostic methods that allow the early detection of bacteria in symptomless citrus trees were developed, including microscopy analysis (6), serological tests such as enzyme-linked immunosorbent assay (ELISA), dot immunobinding assay (DIBA), western blotting (7, 20,25,32), immunofluorescence (35), and polymerase chain reaction (PCR)-based assays $(4,12,17,34,42)$. So far, the PCR-based method is considered the quickest and most efficient method of detecting $X$. fastidiosa in symptomless CVC-infected trees (4), and has been used routinely for this purpose. The PCR-based method described by Pooler and Hartung (42) is useful for detecting only CVC-causing strains, and allows the detection of 10 to 100 bacteria per amplification reaction. However, this PCR approach provides only qualitative detection.

Competitive PCR-based quantification of plant pathogenic fungi in infected plants has been reported $(36,39,47)$. Hyman et al. (23) described the first PCR-based quantitative method for a bacterial plant pathogen, which was Erwinia carotovora on potato tubers. However, the competitive PCR method is labor intensive and has a high risk of carryover contamination (9). Recent developments in PCR technology have improved the quantification of phytopathogenic bacteria. The 5'-nuclease quantitative PCR assay (18) represents a significant advance for measuring input target nucleic acid templates quantitatively. The principle of this real-time PCR has been described elsewhere $(18,28,41)$. Briefly, this method requires the inclusion in the reaction mix of a dual-labeled fluorescent nonextendable probe that anneals specifically to the target DNA between the forward and reverse primer sites (18). The fluorescent emission from the sample occurs because the reporter fluorophore is released due to the endogenous $5^{\prime}-3^{\prime}$ exonuclease activity of the DNA polymerase. Unlike other quantitative PCR methods, such as competitive PCR, the 5'-nuclease quantitative PCR assay (i) does not require post-PCR sample handling, thus 
preventing potential PCR product carry-over contamination; (ii) is less labor intensive, and (iii) does not have a plateau effect because the assay is not based on an endpoint measurement (18).

A real-time quantitative PCR (QPCR) assay for $X$. fastidiosa using the 5'-nuclease PCR was assessed in assays designed to (i) examine temporal and spatial distributions of the bacterium in xylem vessels of experimentally infected citrus leaves and (ii) evaluate the differential multiplication of $X$. fastidiosa in xylem vessels of leaves from CVC-resistant and -susceptible cultivars of citrus and their hybrids. We were able to quantify $X$. fastidiosa and determine temporal and spatial patterns of translocation and differential accumulation of the bacterium in inoculated citrus cultivars.

\section{MATERIALS AND METHODS}

$X$. fastidiosa culture and DNA extraction. $X$. fastidiosa strain $9 \mathrm{a} 5 \mathrm{c}$, whose complete genome has been sequenced (48), was grown on supplemented periwinkle wilt-agar medium (16) at $28^{\circ} \mathrm{C}$ and subcultured every 14 days. Bacterial cells were used for the establishment of standard curves and the artificial infection of citrus trees. Dilution plating on buffered charcoal yeast extract (10 10-fold dilutions) as described by Wells et al. (53) was used to estimate the number of viable bacterial cells (CFU).

In order to extract DNA under conditions similar to those encountered in field samples, we mixed a bacterial suspension containing $1.63 \times 10^{6} \mathrm{CFU}$ of $X$. fastidiosa with $150 \mathrm{mg}$ of a freezeground xylem tissue from leaves of a healthy Pera sweet orange tree, then performed the extraction of DNA on the cell-spiked material as described by Murray and Thompson (38) and modified by Machado et al. (31). The DNA resulting from the extraction process was resuspended in $15 \mu \mathrm{l}$ of Tris- $\mathrm{HCl}, 1 \mathrm{mM}, \mathrm{pH} 7.5$, and EDTA, $0.1 \mathrm{mM}, \mathrm{pH} 8.00$, and the concentration was adjusted to $100 \mathrm{ng} / \mu \mathrm{l}$, so that each microliter contained the amount of DNA found in $1.09 \times 10^{5} \mathrm{CFU}$ of $X$. fastidiosa. DNA concentration and purity were assessed by comparison with known DNA standards in an ethidium bromide-stained $1 \%$ agarose gel (45) and by spectrophotometry at $260 \mathrm{~nm}$. The mixture of $X$. fastidiosa and citrus genomic DNA was stored at $-20^{\circ} \mathrm{C}$.

Real-time QPCR primers and probe. The X. fastidiosa nucleotide sequence used for the design of the primers and TaqMan probe was first described by Pooler and Hartung (42) (GenBank Accession No. AE003946). The sequence for the forward primer CVC-1 (5'-AGA TGA AAA CAA TCA TGC AAA-3'; 424-404 bp) was obtained from Pooler and Hartung (42), and the reverse primer CCSM-1 (5'-GCG CAT GCC AAG TCC ATA TTT-3'; 306-286 bp) was designed for this work based on the target sequence. The TaqMan probe TAQCVC (5'-(6FAM)AAC CGC AGC AGA AGC CGC TCA TC(TAMRA)p-3'; 335-313 bp) also was designed based on the target sequence and carries a fluorescent reporter dye (6-carboxy-fluorescein, $\lambda_{\mathrm{em}}=518$ ) added to the $5^{\prime}$ end and a fluorescent quencher dye (6-carboxytetram-ethylrhodamine, $\lambda_{\mathrm{em}}=582$ ) and a phosphate group (p) added to the $3^{\prime}$ end. Both primers and the TAQCVC probe were synthesized by Applied Biosystems (Foster City, CA). The CCSM-1 primer and the probe were designed using the Primer Express software (version 3.1; Applied Biosystems).

Real-time QPCR assay reaction conditions. The amplification was performed in a $25-\mu \mathrm{l}$ reaction. The reaction mix was slightly modified from that given in the ABI PRISM 7700 User's Manual: $12.5 \mu \mathrm{l}$ of TaqMan Universal PCR Master Mix, $525 \mathrm{nM}$ of each primer (CVC-1 and CCSM-1), $500 \mathrm{nM}$ TAQCVC probe, and the different DNA concentrations used throughout this work. The master mix contained a passive reference dye, ROX, which is used to standardize the reaction (18). In all experiments, appropriate negative controls containing no template DNA were subjected to the same procedure. Each sample was tested in triplicate. For amplification, the recommended universal thermal cycler pro- tocol was used: a $50^{\circ} \mathrm{C}$ hold for $2 \mathrm{~min}$ (uracil-N-glycosylase [UNG] digestion, in an effort to prevent PCR product carryover), a $95^{\circ} \mathrm{C}$ hold for 10 min (activation of AmpliTaq Gold DNA polymerase and denaturation of UNG and the matrix DNA), and then 40 cycles of $15 \mathrm{~s}$ at $95^{\circ} \mathrm{C}$ and $1 \mathrm{~min}$ at $60^{\circ} \mathrm{C}$ (annealing and polymerization steps were combined). Applied Biosystems supplied all consumables. Amplification and data analysis were carried out in an ABI PRISM 7700 Sequence Detector System (Applied Biosystems). Data were analyzed using the Sequence Detector Software 1.6 software as described by the manufacturer. All reactions were analyzed by agarose gel electrophoresis to confirm that only the expected PCR product was amplified.

Real-time QPCR of $X$. fastidiosa from artificially infected citrus. Eight trees each of 'Pera' sweet orange (Citrus sinensis (L.) Osbeck) and 'Murcott' tangor (Citrus reticulata Blanco $\times C$. sinensis (L.) Osbeck) cultivars and one plant of each of the hybrids H-19, H-31, H-55, H-61, H-80, H-129, H-214, and H-243 (belonging to the Germoplasm Active Bank of the Sylvio Moreira Citriculture Center, Agronomic Institute of Campinas, Cordeirópolis, SP, Brazil) were artificially infected with $20 \mu \mathrm{l}$ of a suspension containing $X$. fastidiosa strain $9 \mathrm{a} 5 \mathrm{c}$ at $10^{8}$ cells per $\mathrm{ml}$ in PBS (sodium phosphate $100 \mathrm{mM}$; $\mathrm{NaCl} 0.85 \%$ ). Artificial infection was carried out by injecting a droplet of the bacterial suspension into the xylem using a fine needle as described by Hill and Purcell (20). Control plants were inoculated with sterile PBS saline solution. In addition, five 'Pera' sweet orange trees were artificially infected by grafting as described by Medina et al. (33). In summary, the CVC-symptomatic branch of 'Valencia' sweet orange (C. sinensis (L.) Osb.) was grafted onto a 'Rangpur' lime rootstock ( $C$. limonia L.). The resulting grafted plants were subsequently grafted onto the rootstock (Rangpur lime) of healthy Pera plants. The control plants were grafted only with the CVCfree Rangpur lime.

DNA from xylem tissue used for QPCR assays was extracted from three sections of infected leaves as follows: (i) petioles collected from 'Murcott' tangor, 'Pera' sweet orange, and the eight hybrids, 5 months after the artificial inoculation; (ii) petioles plus the initial two-thirds of the midrib; and (iii) the final one-third of the midrib. Samples ii and iii were collected from leaves of three different ages: 2- and 8-month-old leaves (symptomless samples), and 12-month-old leaves (symptomatic samples), from 'Pera' sweet orange trees infected with $X$. fastidiosa by grafting. Sample number i was obtained from 16 leaves. Samples ii and iii were collected from 16 leaves, previously inoculated with $X$. fastidiosa. Each sample type was ground in liquid nitrogen until a fine powder was obtained. DNA was extracted from $150 \mathrm{mg}$ of the ground samples according to a method modified by Machado et al. (31). The concentration of each DNA sample was adjusted to $100 \mathrm{ng} / \mu \mathrm{l}$ and its purity was determined as described previously (45). Each DNA sample was tested in triplicate in QPCR assays.

The number of $X$. fastidiosa cells in each sample was estimated from a standard curve constructed by plotting the mean $\mathrm{C}_{\mathrm{T}}$ values (cycle threshold, calculated as the first cycle PCR at which a statistically significant increase in the reporter fluorescence can first be detected) for each template DNA dilution ( $y$ axis) against the $\log _{10}$ of the initial quantity of template DNA ( $x$ axis) for each run.

\section{RESULTS}

Specificity of $X$. fastidiosa real-time QPCR assay. Pooler and Hartung (42) found a DNA sequence specific for CVC-causing strains of $X$. fastidiosa. An extensive search of the GenBank database indicated that this DNA sequence (GenBank Accession No. AE003946) (i) shared no significant identity with other known nucleotide sequences; (ii) encodes a hypothetical protein, according to the GenBank Accession No. NC_002488-1; and (iii) constitutes a unique genomic region, without repetitions in the genome of the CVC-causing strain 9a5c of $X$. fastidiosa (48). The TAQCVC 
probe and CCSM-1 reverse primer were designed based on this region's sequence. There is only a single copy of this DNA sequence in $X$. fastidiosa strain 9a5c; therefore, there should be only one template per cell. Known amounts of $X$. fastidiosa genomic DNA corresponding to $X$. fastidiosa populations from $1.09 \times 10^{0}$ to $1.09 \times 10^{5} \mathrm{CFU}$ were used in the construction of standard curves. In this assay, an increase in fluorescent signal above a preset threshold within 40 PCR cycles was considered positive (i.e., $\mathrm{C}_{\mathrm{T}}<40$ ). The amplification plot (fluorescent emission for each reaction versus the number of PCR cycles) and a standard curve from these data are shown in Figure 1A and B, respectively. With increasing amounts of $X$. fastidiosa genomic DNA the respective $C_{T}$ values ranged from 21.97 to 39.71 (Fig. 1A). Under the PCR conditions tested, the standard curve obtained was linear over five orders of magnitude, from 10.9 to 109,000 initial copies of template DNA per reaction, with the corresponding linear regression coefficient of $r^{2}=0.967[y=-3.7887 x \ln (X$. fastidiosa genomic DNA copy number) + 41.901] (Fig. 1B). The PCR-amplification produced a single expected band of $137 \mathrm{bp}$ as confirmed by gel electrophoresis. After 40 rounds of amplification, no PCR products were detected in any of the negative control samples that contained all reagents except the $X$. fastidiosa genomic DNA (data not shown).
The reliability and reproducibility of the real-time QPCR assays also were assessed. According to Locatelli et al. (30), the standard curves for QPCR require high repeatability (when repeated measurements are taken with the same material in a single assay) and reproducibility (repeated measurements are taken in different assays). The $X$. fastidiosa real-time QPCR appeared to be highly reproducible, because the coefficient of variation $(\mathrm{CV})$ ranged from 0.54 to $1.98 \%$ in intraassay variability and 0.81 to $2.51 \%$ in interassay measurements (Table 1). No statistical difference was found between the intraassay and interassay $\mathrm{CV}(P>0.29, t$ test $)$ determined from three standard curves performed on different days and starting from new dilutions of the DNA mixture citrus$X$. fastidiosa. Standard curves revealed high precision and reproducibility, as indicated by correlation coefficients no lower than $r=0.993$.

The specificity of the $X$. fastidiosa real-time QPCR assay was tested using genomic DNA from 12 citrus endophytic bacteria, four strains of $X$. fastidiosa responsible for causing disease on other plants, and 9 other CVC-causing strains of $X$. fastidiosa isolated from a wide range of citrus cultivars and from a number of different geographical locations (2,3) (Table 2). Neither the endophytic bacteria nor the strains of $X$. fastidiosa associated with diseases of other plants showed an increase in fluorescence signal

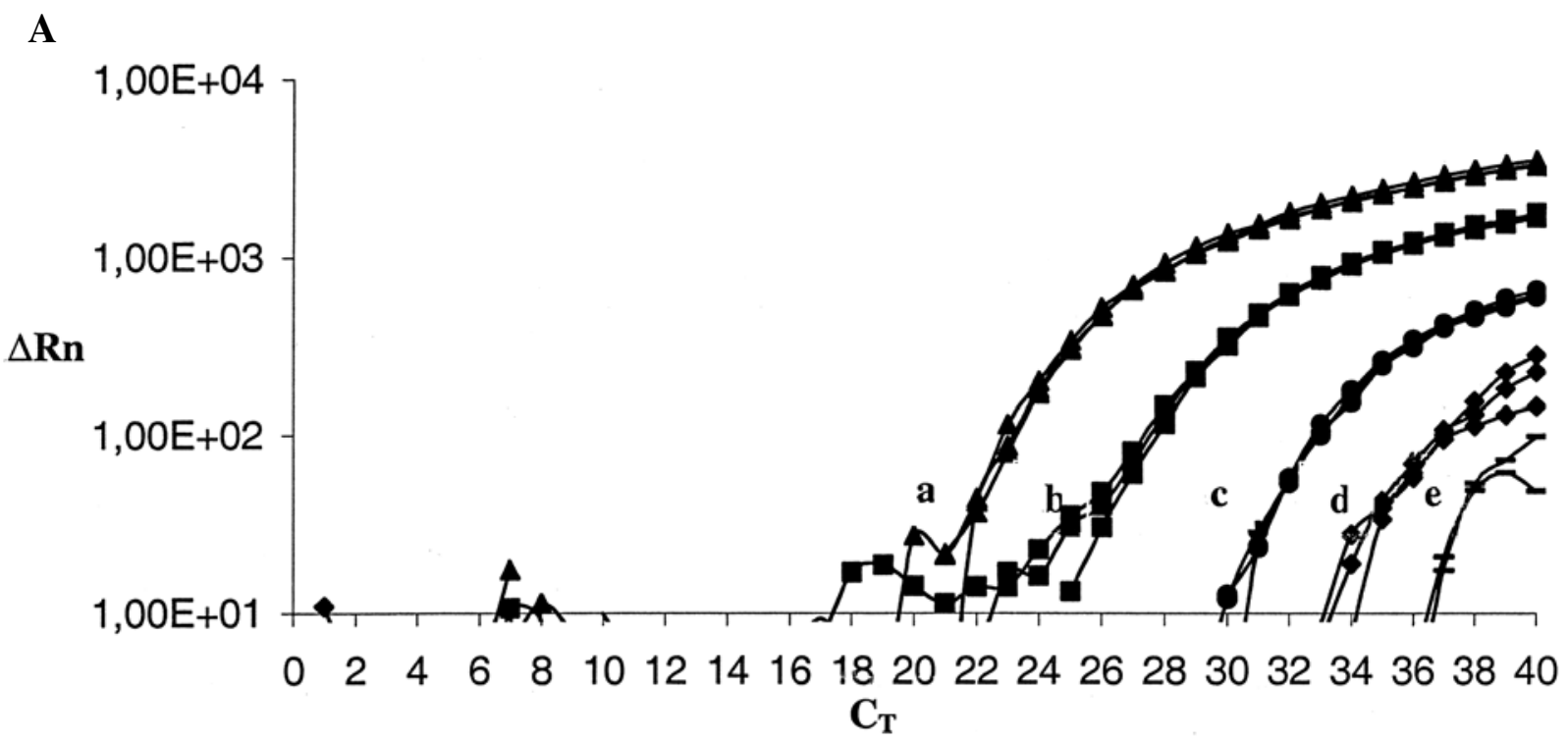

B

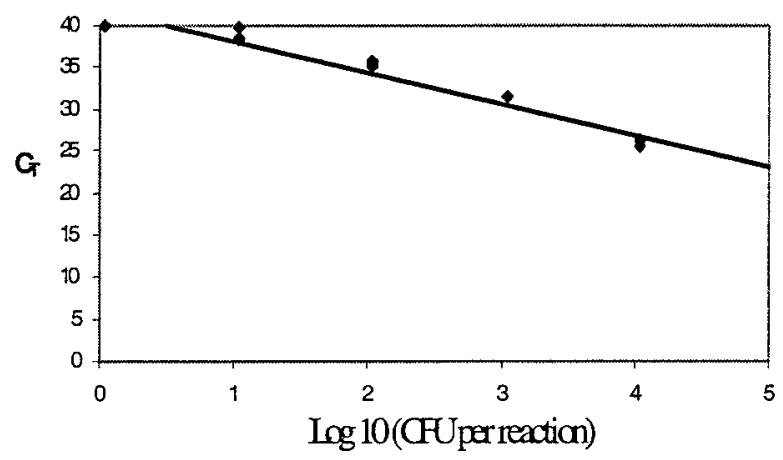

Fig. 1. Real-time quantitative polymerase chain reaction (PCR) of CFU of Xylella fastidiosa using the CVC-1 and CCSM-1 primers and TAQCVC fluorescence probe. A, Amplification plot of the $X$. fastidiosa standards. Amplification plot of normalized fluorescence intensity change $\left(\Delta \mathrm{R}_{\mathrm{n}}\right)$ versus PCR cycle number. The $y$ axis $\left(\Delta \mathrm{R}_{\mathrm{n}}\right)$ is plotted in log scale. The experiment, done in triplicate, consisted of serial 10-fold dilutions of $X$. fastidiosa genomic DNA, corresponding to $1.09 \times 10^{0}$ to $1.09 \times 10^{5} \mathrm{CFU}$ of $X$. fastidiosa, which were used in the construction of standard curves. This is a computerized evaluation of the data obtained using the ABI PRISM 7700 Sequence Detection System. The $x$ axis indicates the PCR cycle, where a, b, c, d, and e are samples with $1.09 \times 10^{5}$ to $1.09 \times 10^{1}$ copies of $X$. fastidiosa genomic DNA, respectively. Fluorescence emission for samples with $1.09 \times 10^{0}$ copies of $X$. fastidiosa genomic DNA was not recorded $\left(\mathrm{C}_{\mathrm{T}} \geq 40\right)$. B, $X$. fastidiosa standard curve. $\mathrm{C}_{\mathrm{T}}$ values are plotted against the log number of $X$. fastidiosa cells in samples of 10-fold dilutions of template DNA. The straight line is calculated by linear regression $(y=-3.7887 x \ln$ [number of DNA copies] $+41,901)$. The linear regression coefficient $\left(r^{2}\right)$ is 0.9678 . A $C_{T}$ value is defined as the PCR cycle where the increase in fluorescence first goes above the baseline. Each point on the curve represents the mean value from three separate PCR amplifications for each dilution. 
during PCR $\left(\Delta \mathrm{R}_{\mathrm{n}}<0.2\right.$ after 40 cycles of amplification; data not shown), indicating the lack of target DNA for the CVC-1 and CCSM-1 primer set. In contrast, all CVC-causing strains exhibited the expected 137-bp band.

Detection and quantification of $X$. fastidiosa from artificially infected citrus. We decided to use the 5 '-nuclease PCR assay to evaluate the movement of the bacterium into vessels of the xylem and its differential multiplication in leaves of CVC-resistant and -susceptible cultivars of citrus. The number of $X$. fastidiosa cells present in citrus tissue samples was calculated by extrapolating the mean $\mathrm{C}_{\mathrm{T}}$ value for the test sample into the standard curve generated with $X$. fastidiosa cells. The number of $X$. fastidiosa cells detected in different xylem regions of 2- and 8-month-old (symptomless), and 12-month-old (symptomatic) leaves of 'Pera' sweet orange are presented in Figure 2. The mean number of $X$. fastidiosa cells detected in the leaf xylem ranged from 0 to $324 X$. fastidiosa cells per $\mathrm{mg}$ of tissue. Bacterial populations increased according to the age of the leaf as described by the linear regression $y=-140.34 x \ln (X$. fastidiosa genomic DNA copy number $)+$ $113.73\left(r^{2}=0.95\right)$, therefore suggesting a temporal accumulation of $X$. fastidiosa in citrus leaf xylem as leaves get older.

$X$. fastidiosa cells were detected in all samples from petioles plus the initial two-thirds of the midrib regardless of their age. In contrast, cells of $X$. fastidiosa were detected only in samples from the upper section of the midrib from 8- and 12-month-old leaves (Fig. 2). These results indicate a spatial distribution of $X$. fastidi-

TABLE 1. Coefficient of variation (\%) of the standard curves for Xylella fastidiosa quantification by real-time quantitative polymerase chain reaction ${ }^{\mathrm{a}}$

\begin{tabular}{lcc}
\hline Input DNA copy number & Intraassay & Interassay \\
\hline $1.09 \times 10^{5}$ & 0.54 & 0.96 \\
$1.09 \times 10^{4}$ & 1.71 & 1.73 \\
$1.09 \times 10^{3}$ & 0.3 & 0.81 \\
$1.09 \times 10^{2}$ & 1 & 2.51 \\
$1.09 \times 10^{1}$ & 1.98 & 2.09 \\
$1.09 \times 10^{0}$ & $\ldots{ }^{\mathrm{b}}$ & $\ldots{ }^{\mathrm{b}}$ \\
\hline
\end{tabular}

${ }^{a}$ Intraassay and interassay variability were estimated by computing the coefficient of variation (ratio between the standard deviation and the mean of repeated measurements).

b No fluorescence above threshold was recorded $\left(C_{T} \geq 40\right)$. osa in the xylem of citrus leaves (i.e., movement of the bacterium from the petiole to the upper midrib).

The number of $X$. fastidiosa cells detected in the leaf petioles of 'Murcott' tangor, 'Pera' sweet orange, and the eight hybrids are presented in Figure 3. The number of cells varied from 0 to $487 X$. fastidiosa cells per $\mathrm{mg}$ of tissue. Pera sweet orange, very susceptible to CVC (24), had 109.2 and 487 X. fastidiosa cells per $\mathrm{mg}$ of tissue when infected by the needle procedure and natural inoculation, respectively. The bacterium was not detected in 'Murcott' tangor, a resistant-citrus cultivar $\left(C_{T} \geq 40\right)$ (Fig. 3).

\section{DISCUSSION}

CVC is a destructive citrus disease in Brazil (26). This article describes the development of a simple, rapid, and reproducible real-time QPCR-based assay for X. fastidiosa detection and its

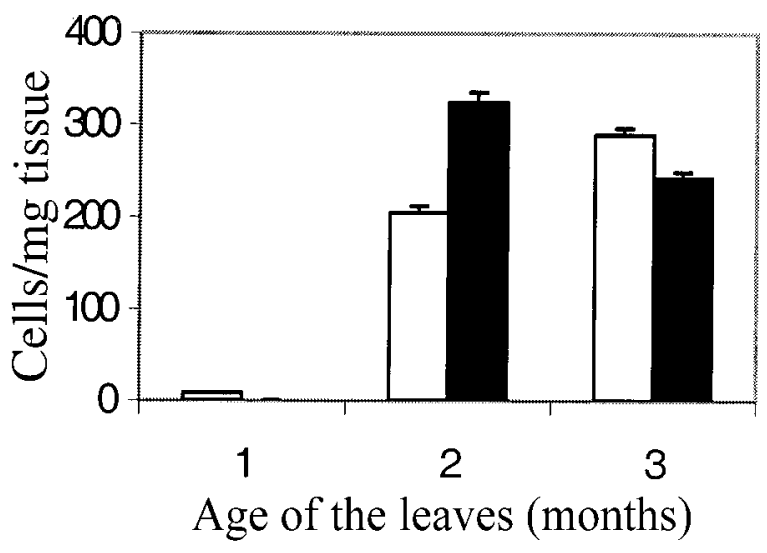

Fig. 2. Temporal-spatial distribution of Xylella fastidiosa cells in leaves of 'Pera' sweet orange quantified by real-time quantitative polymerase chain reaction. The $x$ axis indicates the age of the leaves: $1=2$ months old, $2=$ 8 months old, and $3=12$ months old. Vertical columns in white and black indicate the number of $X$. fastidiosa cells detected in the petioles plus the initial two-thirds of the midrib and in the upper section of the midrib, respectively. Each sample was tested in triplicate. Vertical bars represent standard errors.

TABLE 2. Endophytic citrus bacterial strains and other strains of Xylella fastidiosa used in this study

\begin{tabular}{|c|c|c|c|c|}
\hline Identification & Species or strain & Host & Geographic source & QPCR assay result ${ }^{\mathrm{a}}$ \\
\hline PF4/9 & Pantoea agglomerans & Citrus reticulata & Frutal/SP & - \\
\hline PR1.5/8 & Enterobacter cloacae & C. reticulata & Novais/SP & - \\
\hline $\mathrm{PF} 1 / 2$ & E. cloacae & C. reticulata & Novais/SP & - \\
\hline CT 03 & Bacillus sp. & Citrange & Cordeirópolis/SP & - \\
\hline $\mathrm{PF} 1 / 8$ & E. cloacae & C. reticulata & Novais/SP & - \\
\hline ER1.6/4 & Methylobacterium mesophilicum & C. sinensis & Novais/SP & - \\
\hline SR1.6/17 & Curtobacterium flaccumfaciens & C. sinensis & Novais/SP & - \\
\hline SR5/3 & M. fujisawaense & C. sinensis & Colina/SP & - \\
\hline TS49 & P. agglomerans & C. sunki & Cordeirópolis/SP & - \\
\hline СТ04 & Alcaligenes sp. & P. trifoliata & Cordeirópolis/SP & - \\
\hline $\mathrm{ER} 2 / 3$ & E. cloacae & C. sinensis & Elisiário/SP & - \\
\hline LD29 & Pseudomonas sp. & C. sinensis & Cordeirópolis/SP & - \\
\hline 11347 & Xylella fastidiosa & C. sinensis & Paraná & + \\
\hline 11067 & $X$. fastidiosa & C. sinensis & Paraná & + \\
\hline 11834 & X. fastidiosa & C. sinensis & Paraná & + \\
\hline 11380 & X. fastidiosa & C. sinensis & Santa Catarina & + \\
\hline 11067 & X. fastidiosa & C. sinensis & Londrina/PR & + \\
\hline 11775 & X. fastidiosa & C. sinensis & Rio Grande do Sul & + \\
\hline M2-1 & X. fastidiosa & C. sinensis & Matão/SP & + \\
\hline Ita D & X. fastidiosa & C. sinensis & Itapetininga/SP & + \\
\hline SL4 & X. fastidiosa & C. sinensis & Sete Lagoas/MG & + \\
\hline 8935 & X. fastidiosa & Grape & Paraná & - \\
\hline 12319 & X. fastidiosa & Periwinkle & Botucatu/SP & - \\
\hline 9746 & X. fastidiosa & Plum & Ponta Grossa/PR & - \\
\hline $\mathrm{C} 13$ & X. fastidiosa & Coffee & Cordeirópolis/SP & - \\
\hline
\end{tabular}

a Absence and presence of signal in the real-time quantitative polymerase chain reaction (QPCR) assay are indicated by - and + , respectively. 
successful use for quantification of the bacterial cells in citrus tissues. In phytopathological studies, real-time QPCR has been employed to quantify virus $(11,37,44,46)$, fungi $(5,55)$, and bacteria (51). To our knowledge, this is the first report of a quantitative PCR detection method for xylem-limited bacteria, as well as the first report of quantification of a citrus pathogen using the 5 '-nuclease PCR assay. Ubiquitous pathogens such as $X$. fastidiosa are present in healthy plants and often survive in the host tissue without inducing symptoms (19). The increased accuracy of detection and quantification obtained with this QPCR assay should facilitate studies of how these pathogens multiply and move in plant tissue (1).

We were able to quantify $X$. fastidiosa from serial dilutions over $5 \log$ units $\left(1.09 \times 10^{1}\right.$ to $\left.1.09 \times 10^{5} \mathrm{CFU}\right)$ showing a strong linear relationship between the log of the starting CFU number and the $\mathrm{C}_{\mathrm{T}}$ value. The lack of amplification products or fluorescent signal in reactions containing genomic DNA of bacteria other than CVCcausing strains of $X$. fastidiosa confirmed the specificity of this QPCR assay.

According to Pooler and Hartung (42), the PCR-based method for diagnosis of CVC-causing $X$. fastidiosa strains allows detection of as few as 10 to 100 bacteria per amplification reaction. The genomic content of a citrus cell is $\approx 0.6 \mathrm{pg} / \mathrm{h}$ aploid DNA (15) and the real-time QPCR assay can detect 10 copies of $X$. fastidiosa DNA in citrus DNA at $15 \mathrm{ng} / \mu \mathrm{l}$; therefore, the lower limit of detection of this assay is 1 bacterium in 1,250 citrus cells or $2.47 \mathrm{fg}$ of bacterial DNA in $1.5 \mathrm{ng}$ citrus DNA. This level of detection already has been reported for Campylobacter jejuni (54) and Phytophthora infestans (5).

The quantification of $X$. fastidiosa in the xylem of 'Pera' sweet orange leaves of different ages indicated that the $X$. fastidiosa concentration is closely associated with the progress of the CVC infection. These results agree with a study in which Machado et al. (32) showed a higher concentration of bacteria in old leaves infected with CVC by western blotting. Fry and Milholland (13) and Hopkins (21) observed that the intensity of symptoms of Pierce's disease on grape in response to infection by X. fastidiosa is related to the bacterial concentration.

In addition, Nunes (40) observed that, during the summer, sweet orange cultivars had high, severe CVC symptoms on leaves formed the previous spring. Our real-time QPCR supports this observation, indicating that bacterial colonization had possibly occurred initially in the xylem of symptomless young leaves formed during the spring followed by an increase in the population over time

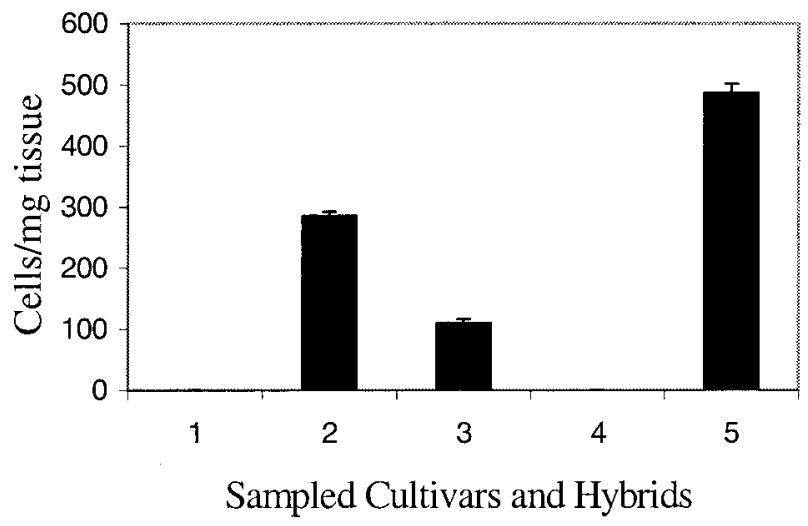

Fig. 3. Number of Xylella fastidiosa cells detected in healthy and in naturally or artificially (by using a needle) infected plants of 'Murcott' tangor, 'Pera' sweet orange, and eight hybrids as determined by real-time quantitative polymerase chain reaction. $1=$ 'Murcott' (needle inoculation), $2=$ hybrids (DNA of the hybrids H-19, H-31, H-55, H-61, H-80, H-129, H-214, and H-243 was bulked) (needle inoculation), 3 = 'Pera' (needle inoculation), $4=$ Healthy 'Pera', and 5 = 'Pera' (naturally infected). Each sample was tested in triplicate. Vertical bars represent standard errors. and, consequently, causing the appearance of foliar symptoms during the summer.

The quantification of $X$. fastidiosa throughout the xylem of 'Pera' sweet orange leaves suggested a pattern of spatial distribution of these bacteria. When the leaves were just 2 months old, the bacteria had not reached the upper midrib $\left(\mathrm{C}_{\mathrm{T}} \geq 40\right)$. By the time they were 8 and 12 months old, bacteria were now present in the xylem region (324 and $242 X$. fastidiosa cells per mg of tissue, respectively). Taking into consideration that the trees used in this work were artificially inoculated through grafting and kept in a sharpshooter-free greenhouse, the colonization of new leaves was caused only by bacteria initially present on those plants. Later on, bacteria moved to petioles, progressively colonizing the midrib until they reached the upper midrib. These results are in agreement with those of Fry and Milholland (13), who observed that the $X$. fastidiosa FC strain first colonized grape leaves closest to the inoculation point. Until now, systemic distribution of CVCcausing strains of $X$. fastidios $a$ had been determined only through conventional PCR in the roots (29), stems, and branches (8) of citrus plants. The TaqMan quantitative PCR assay also has been used to study the spatial distribution of the fish pathogen Pseudomonas plecoglossicida in tissues of fish (49) and for planktonic microbial groups (50).

Quantification of $X$. fastidiosa cells in petioles of 'Pera' sweet orange leaves (109.2 and 487 X. fastidiosa cells per mg of tissue) and 'Murcott' tangor (none) determined by our real-time QPCR assay confirmed the susceptible and resistant status of these citrus cultivars (24). Hopkins (22) pointed out that the ability of $X$. fastidiosa strains to move through xylem vessels is indicative of their pathogenicity. Our results are in agreement with previously published data where the multiplication and spread of $X$. fastidios $a$ occurs faster within the more susceptible cultivars and species of grapevine (20). In the Xylella-grapevine pathosystem, there is a close association between the degree of intervessel migration of the bacteria within the petiole and the amount of resistance observed (13).

In summary, the real-time QPCR method described in this report has been used to quantify $X$. fastidiosa in citrus tissues and was found to be straightforward, sensitive, and reproducible. It provides a convenient tool that can be used to study different aspects of CVC development on citrus. The use of resistant or tolerant cultivars is the most effective CVC control method; therefore, research must first identify sources of resistance or tolerance (26). This novel real-time QPCR assay should be very useful in such breeding programs.

\section{ACKNOWLEDGMENTS}

This research was supported by PRONEX, FAPESP (Proc. 98/06217-0 and 98/14360-5), and CNPq. We thank two anonymous referees for their suggestions and comments, and G. Astua-Monge for critical reading of the manuscript.

\section{LITERATURE CITED}

1. Almeida, R. P. P., Pereira, E. F., Purcell, A. H., and Lopes, J. R. S. 2001. Multiplication and movement of a citrus strain of Xylella fastidiosa within sweet orange. Plant Dis. 85:382-386.

2. Araújo, W. L. 2000. A comunidade bacteriana endofítica de citros e sua interação com Xylella fastidiosa, agente causal da clorose variegada dos citros (CVC). Tese de Doutorado, ESALQ, Piracicaba, Brazil.

3. Araújo, W. L., Maccheroni, W., Jr., Aguilar-Vildoso, C. I., Barroso, P. A., Saridakis, H. O., and Azevedo, J. L. 2001. Variability and interactions between endophytic bacteria and fungi isolated from leaf tissues of citrus rootstocks. Can. J. Microbiol. 47:229-236.

4. Beretta, M. J. G., Barthe, G. A., Ceccardi, T. L., Lee, R. F., and Derrich, K. S. 1997. A survey for strains of Xylella fastidiosa in citrus affected by citrus variegated chlorosis and citrus blight in Brazil. Plant Dis. 81:1196-1198.

5. Bohm, J., Hahn, A., Schubert, R., Bahnweg, G., Adler, N., Nechwatal, J., 
Oehlmann, R., and Osswald, W. 1999. Real-time quantitative PCR: DNA determination in isolated spores of the mycorrhizal fungus Glomus mosseae and monitoring of Phytophthora infestans and Phytophthora citricola in their respective host plants. J. Phytopathol. 147:409-416.

6. Chagas, C. M., Rosseti, V., and Beretta, M. J. G. 1992. Electron microscopy studies of a xylem-limited bacterium in sweet orange affected with citrus variegated chlorosis disease in Brazil. J. Phytopathol. 134:306312.

7. Chang, C. J., Garnier, M., Zreik, L., Rossetti, V., and Bové, J. M. 1993. Culture and serological detection of the xylem-limited bacterium causing citrus variegated chlorosis and its identification as a strain of Xylella fastidiosa. Curr. Microbiol. 27:137-142.

8. Coletta Filho, H. D., Carlos, Targon, M. L. P. N., Cristofani, M., Souza, A. A., and Machado, M. A. 2000. Distribution of Xylella fastidiosa within sweet orange trees: Influence of age and level of symptom expression of citrus variegated chlorosis. Pages 234-237 in: Proc. IOCV Conf. 14, Brazil.

9. Dolken, L., Schuler, F., and Dolken, G. 1998. Quantitative detection of $\mathrm{t}(14 ; 18)$-positive cells by real-time quantitative PCR using fluorogenic probes. Biotechniques 25:1058-1064.

10. Donadio, L. C., and Moreira, C. S., eds. 1997. Clorose variegada dos citros. EECB, Bebedouro, Brazil.

11. Eun, A. J. C., Seoh, M. L., and Wong, S. M. 2000. Simultaneous quantitation of two orchid viruses by the TaqMan real-time RT-PCR. J. Virol. Methods 87:151-160.

12. Ferreira, H., Gonçalves, E. R., Rodrigues Neto, J., and Rosato, Y. B. 2000. Primers specific for Xylella fastidiosa based on RAPD differential fragments. Summa Phytopathol. 26:15-20.

13. Fry, S. M., and Milholland, R. D. 1990. Multiplication and translocation of Xylella fastidiosa in petioles and stems of grapevine resistant, tolerant, and susceptible to pierces disease. Phytopathology 80: 61-65.

14. FUNDECITRUS. 2000. Manual de convivência com a CVC. Fundo Paulista de Defesa da Citricultura, Araraquara, Brazil.

15. Guerra, M. 1984. Cytogenetics of rutaceae. II. Nuclear DNA content. Caryologia 37:219-226.

16. Hartung, J. S., Beretta, M. J. G., Brlansky, R. H., Spisso, J., and Lee, R. F. 1994. Citrus variegated chlorosis bacterium: Axenis culture, pathogenIcity, and serological relationships with other strains of Xylella fastidiosa. Phytopathology 84:591-597.

17. He, C. X., Ciapina, L. P., Li, W. B., Donadio, L. C., and Lemos, E. G. M. 1996. ERIC-PCR for early detection of bacterium (Xylella fastidiosa) of citrus variegated chlorosis. Pages 20-25 in: Annu. Meet. Int. Soc. Trop. Hortic. 42, Brazil.

18. Heid, C. A., Stevens, J., Livak, K. J., and Williams, P. M. 1996. Real time quantitative PCR. Genome Res. 6:986-994.

19. Henson, J. M., and French, R. 1993. The polymerase chain reaction and plant disease diagnosis. Annu. Rev. Phytopathol. 31:81-109.

20. Hill, B. L., and Purcell, A. H. 1995. Multiplication and movement of Xylella fastidiosa within grapevine and four other plants. Phytopathology 85:1368-1372.

21. Hopkins, D. L. 1985. Physiological and pathological characteristics of virulent and avirulent strains of the bacterium that causes Pierce's disease of grapevine. Phytopathology 75:713-717.

22. Hopkins, D. L. 1989. Xylella fastidiosa: Xylem-limited bacterial pathogen of plants. Annu. Rev. Phytopathol. 22:271-290.

23. Hyman, L. J., Birch, P. R. J., Dellagi, A., Avrova, A. O., and Toth, I. K. 2000. A competitive PCR-based method for the detection and quantification of Erwinia carotovora subsp. atroseptica on potato tubers. Lett. Appl. Microbiol. 30:330-335.

24. Laranjeira, F. F., Pompeu, J., Jr., Harakava, R., Figueiredo, J. O., Carvalho, S. A., and Coletta Filho, H. D. 1998. Cultivares e espécies cítricas hospedeiras de Xylella fastidiosa em condições de campo. Fitopatol. Bras. 23:147-154.

25. Lee, R. F., Beretta, M. J. G., Derrick, K. S., and Hooker, M. E. 1992. Development of a serological assay for citrus variegated chlorosis: A new disease of citrus in Brazil. Proc. Fla. State Hortic. Soc. 105:32-35

26. Li, W. B., Donadio, L. C., Beretta, M. J. G., Rossetti, V., and Sempionato, O. R. 1996. Practical methods for resistance evaluations of citrus varieties to citrus variegated chlorosis. Proc. Int. Soc. Citricult. 1:276-279.

27. Li, W. B., Zreik, L., Fernandes, N. G., Miranda, V. S., Teixeira, D. C., Ayres, A. J., Garnier, M., and Bové, J. M. 1999. A triply cloned strain of Xylella fastidiosa multiplies and induces symptoms of citrus variegated chlorosis in sweet orange. Curr. Microbiol. 39:106-108.

28. Lie, Y. S., and Petropoulos, C. J. 1998. Advances in quantitative PCR technology: 5' Nuclease assays. Curr. Opin. Biotechnol. 9:43-48.
29. Lima, J. E. O., Coutinho, A., Roberto, S. R., Miranda, V. S., Carlos, E. F., Salva, R., and Massari, C. 1996. New developments on citrus variegated chlorosis research at Fundecitrus, Brazil. Proc. Intl. Soc. Citricult. 2:435-439.

30. Locatelli, G., Santoro, F., Veglia, F., Gobbi, A., Lusso, P., and Malnati, M. S. 2000. Real-time quantitative PCR for human herpesvirus 6 DNA. J. Clin. Microbiol. 38:4042-4048.

31. Machado, M. A., Colleta Filho, H. D., Targon, M. L. P. N., and Pompeu, J., Jr. 1996. Genetic relationship of Mediterranean mandarins (Citrus deliciosa tenore) using RAPD markers. Euphytica 92:321326.

32. Machado, M. A., Targon, M. L. P. N., Beretta, M. J. G., Laranjeira, F. F., and Carvalho, S. A. 1997. Detecção de Xylella fastidiosa em espécies e variedades de citros sobre-enxertadas em laranja 'pêra' com clorose variegada de citros (CVC). Fitopatol. Bras. 22:30-33.

33. Medina, C. L., Nunes, W. M. C., Machado, M. A., and Machado, E. C. 1998. Método prático para transmissão de Xylella fastidiosa em mudas de citros. (Abstr.) Fitopatol. Bras. 23:212.

34. Minsavage, G. V., Thompson, C. M., Hopkins, D. L., Leite, R. M. V. B. C., and Stall, R. E. 1994. Development of a polymerase chain reaction protocol for detection of Xylella fastidiosa in plant tissue. Phytopathology 84:456-461.

35. Monteiro, P. B., Renaudin, J., Jagoueix-Eveillard, S., Ayres, A. J., Garnier, M., and Bové, J. M. 2001. Catharanthus roseus, an experimental host plant for the citrus strain of Xylella fastidiosa. Plant Dis. 85: 246-251.

36. Moukhamedov, R., Hu, X., Nazar, R. N., and Robb, J. 1994. Use of polymerase chain reaction-amplified ribosomal intergenic sequences for the diagnosis of Verticillium-tricorpus. Phytopathology 84:256-259.

37. Mumford, R. A., Walsh, K., Barker, I., and Boonham, N. 2000. Detection of potato mop top virus and tobacco rattle virus using a multiplex realtime fluorescent reverse-transcription polymerase chain reaction assay. Phytopathology 90:448-453.

38. Murray, M. G., and Thompson, W. F. 1980. Rapid isolation of high molecular weight plant DNA. Nucleic Acids Res. 8:4321-4325.

39. Nicholson, P., Doohan, F., Rezanoor, H. N., Simpson, D., Smith, P. H., Turner, A., and Weston, G. 1997. Detection and quantification of individual fungal species in Fusarium disease complexes of cereals by polymerase chain reaction (PCR). Cereal Res. Commun. 25:477482.

40. Nunes, W. M. C. 1999. Epidemiologia da clorose variegada dos citros (CVC) avaliada por sintomas e diagnóstico serológico e molecular de Xylella fastidiosa. Tese de Doutorado. UNESP, Botucatu, Brazil.

41. Orlando, C., Pinzani, P., and Pazzagli, M. 1998. Developments in quantitative PCR. Clin. Chem. Lab. Med. 36:255-269.

42. Pooler, M. R., and Hartung, J. S. 1995. Specific PCR detection and identification of Xylella fastidiosa strains causing citrus variegated chlorosis. Curr. Microbiol. 31:377-381.

43. Rasmussen, O. F., and Reeves, J. C. 1992. DNA probes for detection of plant pathogenic bacteria. J. Biotechnol. 25:203-220.

44. Roberts, C. A., Dietzgen, R. G., Heelan, L. A., and Maclean, D. J. 2000. Real-time RT-PCR fluorescent detection of tomato spotted wilt virus. J. Virol. Methods 88:1-8.

45. Sambrook, J., Fritsch, E. F., and Maniatis, T. 1989. Molecular Cloning: A Laboratory Manual. Cold Spring Harbor Laboratory, Cold Spring Harbor, NY.

46. Schoen, C. D., Knorr, D., and Leone, G. 1996. Detection of potato leafroll virus in dormant potato tubers by immuno-capture and a fluorogenic 5' nuclease RT-PCR assay. Phytopathology 86:993-999.

47. Simon, L., Lévesque, L., and Lalonde, R. C. M. 1992. Rapid quantitation by PCR of endomyycorrhizal fungi colonizing roots. PCR Methods Appl. 2:76-80.

48. Simpson, A. J. G., Reinach, F. C., Arruda, P. 2000. The genome sequence of the plant pathogen Xylella fastidiosa. Nature 406:151-157.

49. Sukenda, W. H. 2000. Tissue distribution of Pseudomonas plecoglossicida in experimentally infected ayu plecoglossus altivelis studied by real-time quantitative PCR. Fish Pathol. 35:223-228.

50. Suzuki, M. T., Taylor, L. T., and Delong, E. F. 2000. Quantitative analysis of small-subunit RNA genes in mixed microbial populations via 5'nuclease assays. Appl. Environ. Microbiol. 66:4605-4614.

51. Weller, S. A., Elphinstone, J. G., Smith, N. C., Boonham, N., and Stead, D. E. 2000. Detection of Ralstonia solanacearum strains with a quantitative, multiplex, real-time, fluorogenic PCR (TaqMan) assay. Appl. Environ. Microbiol. 66:2853-2858.

52. Wells, J. M., Raju, B. C., Jung, H. Y., Weisburg, W. G., Mandelco-Paul, L., and Brenner, D. J. 1987. Xylella fastidiosa gen nov., sp. nov. gram negative, xylem limited fastidious plant bacteria related to Xanthomonas spp. Int. J. Syst. Bacteriol. 37:859-862.

53. Wells, J. M., Raju, B. C., Nyland, G., and Lowe, S. K. 1991. Medium for 
isolation and growth of bacteria associated with plum leaf scald and honey peach diseases. Appl. Environ. Microbiol. 42:357-363.

54. Wilson, D. L., Abner, S. R., Newman, T. C., Mansfield, L. S., and Linz, J. E. 2000. Identification of ciprofloxacin-resistant Campylobacter jejuni by use of a fluorogenic PCR assay. J. Clin. Microbiol.
38:3971-3978.

55. Zhang, A. W., Hartman, G. L., Curio-Penny, B., Pedersen, W. L., and Becker, K. B. 1999. Molecular detection of Diaporthe phaseolorum and Phomopsis longicolla from soybean seeds. Phytopathology 89: 796-804. 